Research Article

\title{
Student's scientific literacy on environmental pollution material based on SETS learning approach combined with Vee Diagram
}

\author{
Rini Rita T. Marpaung a,1, , Berti Yolida a,2, Faradilla Riana Putri a,3 \\ a Biology Education Department, Faculty of Teacher Training and Education, University of Lampung, Jl. Prof. Dr. Soemantri \\ Brojonegoro, No. 1, Bandar Lampung, Lampung 35141, Indonesia \\ ritamarpaung207@gmail.com*; ${ }^{*}$ berti.yolida@fkip.unila.ac.id, ${ }^{3}$ faradillariana@gmail.com \\ ${ }^{*}$ Corresponding author
}

\begin{tabular}{|c|c|}
\hline ARTICLE INFO & ABSTRACT \\
\hline \multirow[t]{2}{*}{$\begin{array}{l}\text { Article history } \\
\text { Received: } 23 \text { February } 2021 \\
\text { Revised: } 21 \text { March } 2021 \\
\text { Accepted: } 27 \text { July } 2021 \\
\text { Published: } 28 \text { July } 2021 \\
\text { Keywords } \\
\text { Scientific literacy } \\
\text { SETS learning approach } \\
\text { Vee diagram }\end{array}$} & $\begin{array}{l}\text { The student's scientific literacy is vital in improving students' awareness of several issues. } \\
\text { This study was intended to describe the effect of the SETS learning approach combined } \\
\text { with Vee Diagram on students' scientific literacy especially on Environmental Pollution } \\
\text { Material. This study used a nonequivalent pretest-posttest control group design. The } \\
\text { survey involved } 60 \text { students who were selected using cluster random sampling technique. } \\
\text { The quantitative data, in terms of pretest, posttest, and N-gain scores were analyzed } \\
\text { using Independent-sample t-test at the } 5 \% \text { significance level. The results showed that, } \\
\text { based in the N-gain scores, the experiment class was classified in moderate category } \\
\text { and the control class belonged to low category. This means that the SETS learning } \\
\text { approach combined with Vee Diagram influence student's scientific literacy on } \\
\text { Environmental Pollution Material. Therefore, this combination is recommended to be } \\
\text { implemented in class to enhance students' scientific literacy skills. }\end{array}$ \\
\hline & $\begin{array}{r}\text { Copyright } \odot \text { 2021, Marpaung, et al } \\
\text { This is an open access article under the CC-BY-SA license }\end{array}$ \\
\hline \multicolumn{2}{|c|}{$\begin{array}{l}\text { How to cite: Marpaung, R. R. T., Yolida, B., \& Putri, F. R. (2021). Student's scientific literacy on environmental pollution material } \\
\text { based on SETS learning approach combined with Vee Diagram. JPBI (Jurnal Pendidikan Biologi Indonesia), 7(2), } \\
\text { 117-125. doi: https://doi.org/10.22219/jpbi.v7i2.15718 }\end{array}$} \\
\hline
\end{tabular}

\section{INTRODUCTION}

Science learning requires a learning approach that can find facts, concepts, and solve problems and issues that occur in the surrounding environment. This situation requires teacher's innovation to change the way of passive learning into active learning, responsive, and meaningful for students and the surrounding community (Burden \& Kearney, 2016; Indriati, 2012; Setiawati \& Corebima, 2018; Suwono et al., 2017). Teachers are also required to carry out the development in the learning process (Chebii et al., 2012; Gultepe, 2016; Saptasari et al., 2019). The learning approach by using SETS (Science, Environment, Technology, And Society) is one of the developments in the learning process that has been researched recently (Sya'ban \& Wilujeng, 2016; Trihastuti, 2017). 
In the industrial revolution 4.0 era, science and technology are developing rapidly, students require to understand technological developments and their impact on the environment. To answer this challenge, one of the skills that must have by the student is scientific literacy (Holbrook \& Rannikmae, 2009; Purwani et al., 2018; Rahayuni, 2016; Suwono et al., 2017). Scientific literacy means respect for science by increasing the components of self-learning to contribute to the environment (Nofiana \& Julianto, 2018). Scientific literacy according to PISA is the ability to use scientific knowledge, identify questions and conclude based on evidence to understand nature changes due to human activities (Bybee et al., 2009). Scientific literacy will greatly help everyone to respond to problems critically as a phenomenon that often occurs, especially those related to science and technology (Novitasari, 2018). The definition of scientific literacy shows that literacy skills not only require students to understand the knowledge of science, but students must also be able to understand various aspects of the scientific process and the ability to apply science knowledge in real life (Hadi et al., 2020).

Based on the interview with one of the science teachers in SMPN 26 Bandar Lampung, showed that the learning outcomes of students were classified as a low category (below the criteria). In addition, students' knowledge of scientific literacy is still relatively low. Teachers have not been able to define scientific literacy skills, indicators of scientific literacy skills, and strategies how to developed scientific literacy skills. In addition, learning science in this school is still focused on memorizing concepts and theories only, the teacher also has not tried to let students make the observations or having a practicum directly (Sya' 'ban \& Wilujeng, 2016). SETS learning approach can be an alternative to improve students' scientific literacy skills. Through this learning approach, students are also expected to understand the linkages between Science, Environment, Technology, and Society on environmental pollution material by applying concepts possessed from various related sciences (Ghofur \& Raharjo, 2018).

The application of the SETS approach in learning was not significant in increasing the students' scientific literacy. Consequently, the SETS approach needs to be integrated with the Vee diagram to enhance the students' scientific literacy. The vee diagram is one of the effective constructive learning strategies (Sofianto et al., 2016). The usage of the Vee diagram is intended to help the learning process using the graph to build knowledge, communication through certain stages, and help students to find something new. Students can understand their role in the learning process and how to continue the progress (Suprapto, 2017). SETS learning approach can be strengthened if combined with Vee diagrams that can improve students' scientific literacy skills (Yuliyati, 2017; Amalia, 2019). According to Bybee et al., (2009) scientific literacy has three competency aspects that can be achieved by students through the SETS learning approach and the Vee diagram, such as: (1) identify scientific issues, (2) explaining scientific phenomena, (3) using scientific evidence (Bybee et al., 2009).

Based on the facts and problems that have been described above, there is still a lack of information related to the using of Vee Diagrams in the SETS learning approach that can improve students' scientific literacy skills on environmental pollution material. So, this study aims to prove the effect of the SETS learning approach combined with Vee Diagrams that is considered capable of improving students' scientific literacy skills on environmental pollution material. Due to the importance of scientific literacy for student's awareness of the environment, health, economy, society, and technology (Pratiwi et al., 2019). Therefore, measuring scientific literacy is important to determine the level of student's scientific literacy to increase the Indonesia education quality in the future.

\section{METHOD}

This research was conducted in February 2020, which took place at SMPN 26 Bandar Lampung. The survey involved 60 students were selected by using cluster random sampling techniques. This study used a quasi-experiment research design with a pretest-posttest nonequivalent control group design technique. This study used two research classes. The first class was the control class that only used the discussion method, while the second class was the experiment class that used the SETS learning approach combined with the Vee diagram. The instruments used in this study were in Table 1.

Table 1. Research instrument

\begin{tabular}{clll}
\hline No. & \multicolumn{1}{c}{ Aspects } & \multicolumn{1}{c}{ Instrument } & Type of Data \\
\hline 1. & Scientific Literacy & Multiple Choice Test & Primary Data \\
2. & Vee Diagram & Essay Test & Primary Data \\
3. & $\begin{array}{l}\text { Responses to the use of SETS Learning } \\
\text { Approach with Vee Diagram }\end{array}$ & Likert scale questionnaire & Secondary Data \\
\hline
\end{tabular}


Data processing in this study was carried out using statistical analysis software SPSS 17.0. Data analysis techniques in this study were instrument test that requires validity, reliability, difficulty level, and difference power tests. The aspects of students' scientific literacy were analyzed using a normalized gain score, normality test, homogeneity test, and the Independent Sample t-test at the 5\% significance level.

\section{RESULTS AND DISCUSSION}

The data results were pretest, posttest, $\mathrm{N}$-gain, and inferential statistics of the control class and experiment class (can be seen in Table 2). Based on the results of the normality test obtained Kolmogorov-Smirnov value sig. $>0,05$, which means that the data is distributed normally, and for the homogeneity test the data is homogenous (Levene-Test sig. > 0.05). The average pretest of the experiment and control class obtained the value of 53,6 and 38,4 sequentially. After treatment was given, it's obtained the average posttest value of the experiment and control class by 72,5 and 65,7 sequentially. Thus, the average value of the experiment class is higher than the control class.

Table 2. The results of data processing of control and experiment class pretest and posttest.

\begin{tabular}{cccccc}
\hline Value & Class & Average \pm up to & Normality test & Homogeneity test & $\begin{array}{c}\text { Independent sample } \\
\text { T-test }\end{array}$ \\
\hline Pre-test & E & $53,6 \pm 7,99$ & 0,200 & 0,251 & Sig. (2- \\
& C & $38,4 \pm 11,59$ & 0,126 & & tailed) \\
Post-test & E & $72,5 \pm 11,51$ & 0,200 & 0,251 & $0,000<0,05$ \\
& C & $65,7 \pm 14,12$ & 0,200 & & \\
N-Gain (\%) & E & $53,3 \pm 0,12$ (Medium) & 0,222 & 0,424 & \\
\hline
\end{tabular}

Note: $\mathrm{E}=$ Experiment; $\mathrm{C}=$ Control

The independent sample t-test result showed that sig. ( 2 tailed) $0,00<0,05$, which means the average $\mathrm{N}$ gain of the cognitive aspect of learning results between control and experiment class is significantly different. The average $\mathrm{N}$-gain value of the experiment class $(53,3)$ is higher than the control class which is only 31,4 .

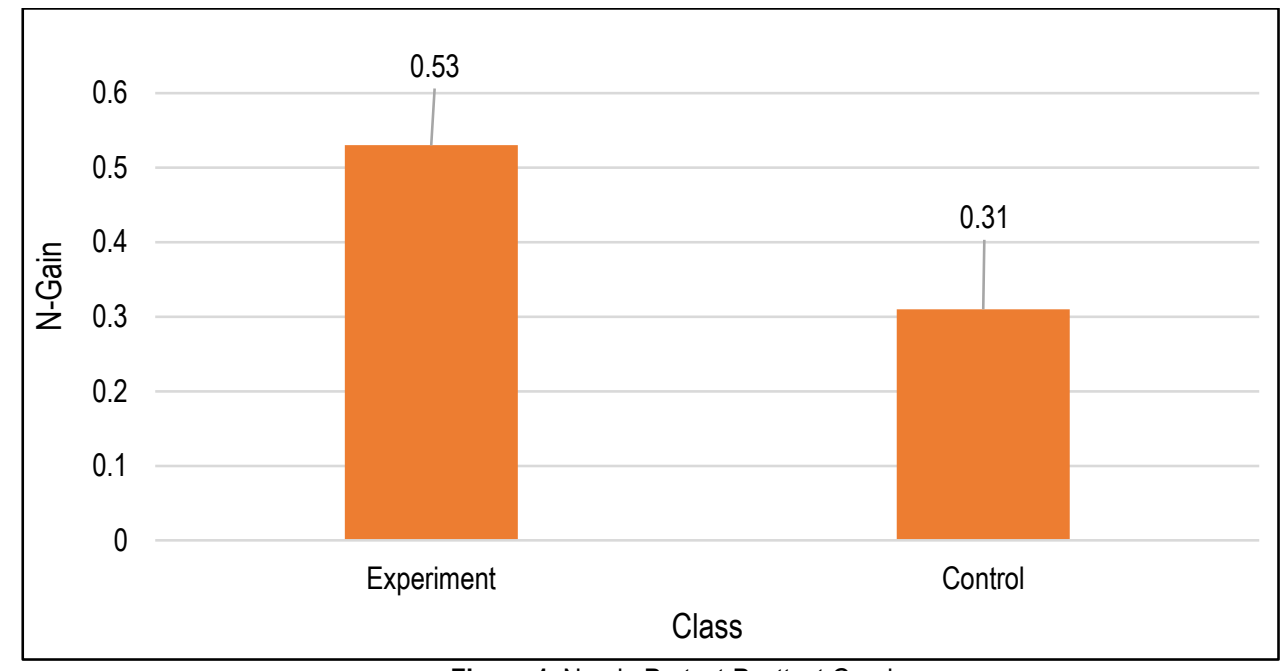

Figure 1. N-gain Pretest-Posttest Graph

The difference in $\mathrm{N}$-gain between the experiment and control class is shown in Figure 1. The average result of the experiment class is higher if compared to the control class because SETS approach learning combined with the Vee diagram requires students to think critically about the problems given and be able to do scientific literacy to find problem solutions during the learning activity. Following the opinion about SETS, the learning approach provides students with an understanding of the role of the environment in science, technology, and society so that students can take advantage of the knowledge (Eliyanti et al., 2019). This is also following the research conducted by Dwipayana (2017) which obtained an N-gain score for STM learning models (Science, Technology, Community) higher than the DI (Direct Instruction) learning model.

Pretest-posttest questions are questions that have been adjusted with the scientific literacy achievements aspects. Scientific literacy aspects examined in this research are (1) defining scientific questions; 
(2) explaining scientific phenomena; and (3) using scientific evidence. Thus, the average value of pretest-posttest based on scientific literacy aspect on experiment and control class can be seen in Figure 2 and Figure 3.

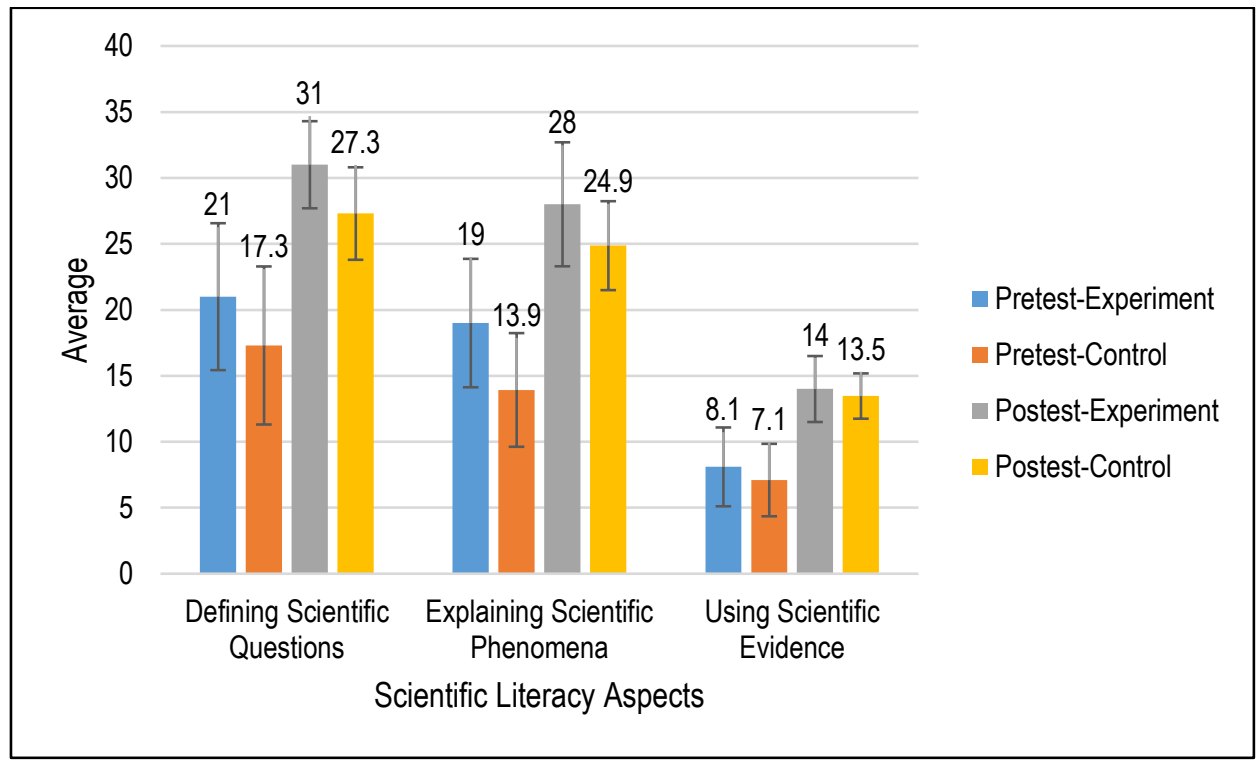

Figure 2. The average value of pretest and post-test based on scientific literacy aspects.

According to Bybee et al., (2009), scientific literacy has three competency aspects that can be achieved by students through the SETS learning approach and the Vee diagram. First, identify scientific issues, which means that students can identify problems for scientific investigation and identify keywords to find scientific information. Second, explaining scientific phenomena, which means that students can apply science in certain situations, describe or interpret scientific phenomena and predict changes, identify appropriate descriptions, provide scientific explanations and predictions. Third, using scientific evidence, which means students can interpret scientific evidence, make conclusions, communicate, identify assumptions, evidence, and reasons behind conclusions, and understand the social implications of science and technology. Based on the average pretest and posttest value based on scientific literacy aspects (Figure 2), both of the classes showed the increase of student's scientific literacy average on the three aspects, but the increasing number of scientific literacy aspects in the control class is not significant than the experiment class. Results conducted by Amalia (2019) showed a significant difference in the student's scientific literacy aspects between the learning process using SETS approach are better than the learning process using discussion method.

The results of the achievement level tests on aspects of scientific literacy competencies indicate that there is a significant influence on the student's scientific literacy abilities in all three aspects by SETS learning approach with Vee diagram. It can be caused by the experiment class using the learning approach at each meeting where the learning phase is always carried out. The students are asked to identify some of the problems presented, then develop science-based investigations to investigate issues related to the source of information obtained previously. The implementation of problem-based learning can improve students' scientific literacy because it can support the learning process that is relevant to the material (Anugrah et al., 2021). Scientific literacy is the ability to understand science, communicate science, and apply science's ability to solve problems. Students shared roles to find solutions to these problems. Different from classes that use the method of discussion, students are only asked to discuss and analyze problems scientifically without being required to do a learning organization to do the stages of getting detailed problem-solving (Yuliati, 2017). Based on the average value of pretest and posttest in each aspect of scientific literacy in the experiment and control class (Figure 3). The N-gain scores of the experiment class in all three aspects of scientific literacy were included in the high category, while the control was included in the low category.

Students in the experiment class are required to be able to present and develop scientific attitudes to solve problems that are presented scientifically as well. Students are also required to be able to modify, discover, and even make technology to solve problems in their environment. Therefore, students must carry out investigations through various reliable reference sources, so the knowledge gained is also comprehensive. The main elements of scientific literacy are the development of scientific literacy students include knowledge of science, scientific processes, development of scientific attitudes, and students' understanding of science so that students not only 
know the concept of science but can also apply scientific skills in solving various problems, and can make decisions based on scientific studies (Harlen, 2014).

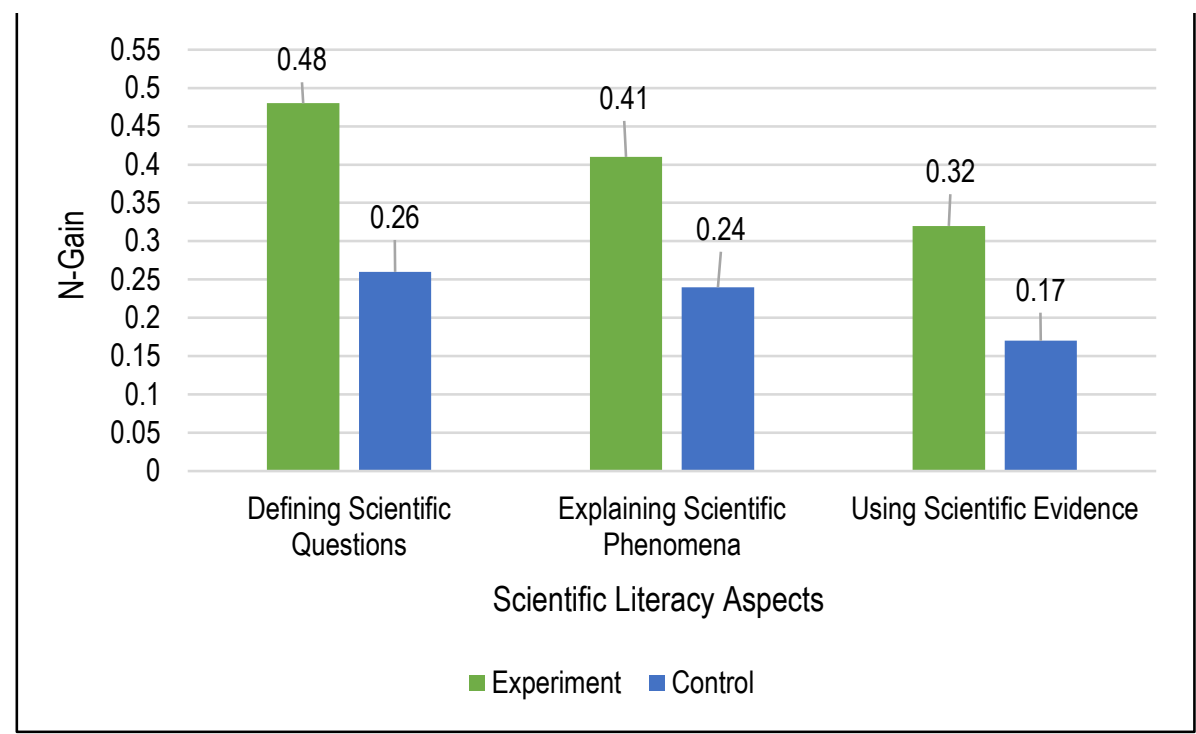

Figure 3. N-gain pretest-posttest graph based on scientific literacy aspects

Unlike the experiment class, the learning process in the control class requires students to investigate the problem and present the process to solve it, but students are not required to modify or create a technology to solve problems in their environment. Students are also not required to present the relationship between science, technology, and society. Hence, that students do not explore knowledge widely and only rely on a few references, for example, schoolbooks without further investigation. This results in a higher average pretestposttest score in the experiment class when compared to the control class which can be interpreted that the scientific literacy ability of the experiment class students tends to be higher than the control class.

The explanation above is in line with research that applies the SETS learning approach to see its effects on students' scientific literacy abilities on environmental pollution material. From all the data obtained in the study, it was clear that the SETS learning approach had a significant effect. SETS learning can help students in understanding science, the development of science and technology, and their impact on the environment and society. Therefore, it can be concluded that the SETS learning model can improve the scientific literacy of students (Trihastuti, 2017). The SETS learning approach provides an opportunity for students in mastering each material. This is based on the characteristics of the SETS learning approach which has systematic stages to require students to construct the knowledge they get. The first step of the SETS learning approach is delivering opinions related to science and technology issues (brainstorming an issue or topic), in this step, students are required to think creatively to clarify the scientific issues and to analyze the relationship with the material being taught (Agustini \& Suardana, 2013). The STS Model (Science, technology, society) could increase science and technology literacy students because it emphasizes the process of gaining knowledge, higher-order thinking skills, problem-solving (Adipura, 2012). In addition, the Vee diagrams can also improve students' scientific literacy because it can help students construct their knowledge by using the worksheet (Yolida et al., 2021).

The score result of Vee diagrams made by students can be seen in Figure 4. Each component of the Vee diagram created by students' scores is indicated very high. Based on the graph, there are four components of the Vee diagrams were assessed, there are Object, Theory/principle/concept, Transformation, and Knowledge Claim. The result shows that the students get very high grades in the four components. It means students are not only able to answer the questions related to the practicum activities, but also links between concepts (thinking) and methods (activity). Vee diagrams can also increase students' motivation in learning, hence it has a good impact on higher-order thinking skills compared to lecture and demonstration learning methods (Wicaksono, 2018). Hindriana (2016) showed that using Vee diagrams as a learning tool is easier in designing learning strategies and practicum in the classroom. Vee diagram has an important role in improving students' scientific literacy skills in the experiment class. The Vee diagram is also consisting of (1) focus question component, (2) conceptually it is divided into conceptual structures (thinking), (3) concepts and objects (events), and (4) methodology (doing) is divided into notes, data transformation/interpretation, knowledge claims and 
claims of values (M. Chaidir et al., 2018). These are good at making students in logical thinking and improve learning outcomes. In addition, Vee diagrams provide students to build connections between theoretical knowledge and work lab activities (Handayani \& Widiantie, 2020). From these results the students are skilled in making focus questions, data/events, recording and transformation of data as well as claim value, however, the concepts and claim knowledge are still lacking. Hence, skills improvement is still needed to continue for the maximum results (Suprapto, 2017).

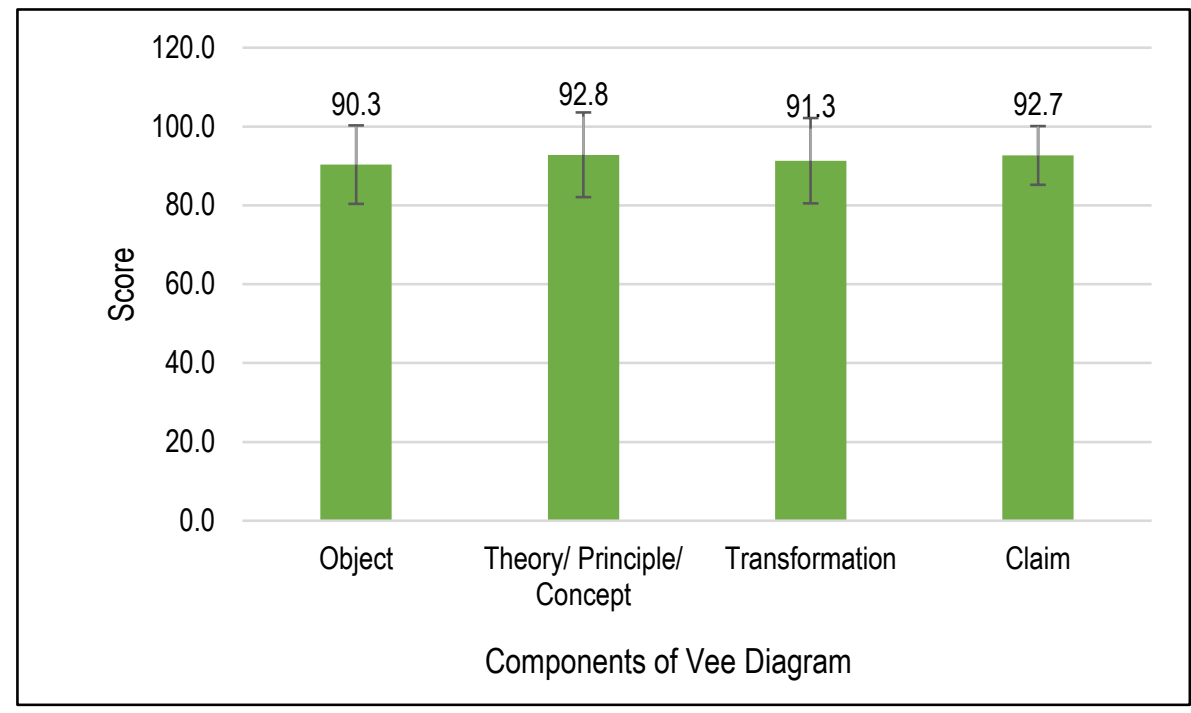

Figure 4. Student's score of Vee diagram

Furthermore, it was also obtained the percentage of student responses data about the implementation of the SETS learning combined with Vee diagrams (Figure 5). It is to find out students' opinions about the learning model for the actual implementation of the study through qualitative data. The results of students' responses to SETS learning with Vee diagrams consist of interests, benefits, and participation. Students showed a higher interest than other aspects of benefits and participation because the Vee diagram in SETS learning is a new thing for students. They usually learned using worksheets with questions such as exams, but this method is more interesting to students than conventional learning.

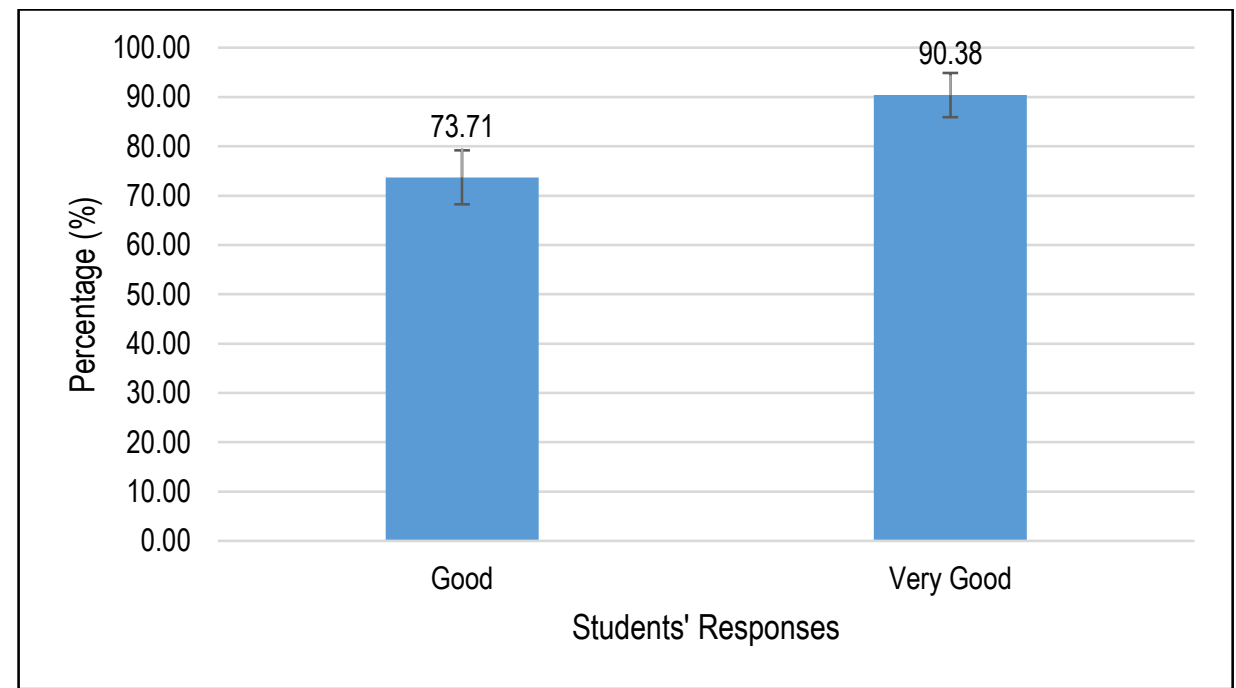

Figure 5. Percentage of student responses to SETS learning with Vee diagrams

The results of the questionnaire are presented in Figure 5 which shows a positive response which is the response of 'very good' and 'good' of the learning approach to the concept of environmental pollution. This is similar to the result of Oktavia (2015) that regarding student participation in class which is a tangible form of 
student behavior in learning activities. Mental and emotional involvement encourage them to contribute and be responsible for achieving satisfactory learning (Ruvalcaba-Romero et al., 2017). This participation can be shown by actively participating in lessons, how students understand the teacher's lessons, asking questions, how students do and collect assignments. Therefore, students can also give a good impression of learning that is applied (Khizar, Rasheed, Iqbal, Akhtar, \& Khalid, 2020).

\section{CONCLUSION}

Based on the results and discussion, it can be concluded that the SETS (Science, Environment, Technology, and Society) learning approach combined with the Vee diagram has a significant effect on increasing the scientific literacy ability of students on Environmental Pollution material, but it still needed an effort to maintain the scientific literacy of all students. The SETS approach with the Vee diagram can be used as a reference for schools to implement science learning due to the result of significantly improve students' scientific literacy skills.

\section{ACKNOWLEDGEMENT}

My highest appreciation is addressed to all parties involved in this study, including the Department of Biology Education, Lampung University, Principal and Teachers of SMPN 26 Bandar Lampung, as well as all the students who participated in this research.

\section{REFERENCES}

Adipura, B. (2012). Pengaruh model pembelajaran Sains-Teknologi-Masyarakat dalam meningkatkan literasi sains dan teknologi ditinjau dari gaya kognitif siswa. Al-Tadzkiyyah: Jurnal Pendidikan Islam, 8, 75-83. https://ejournal-pasca.undiksha.ac.id/index.php/jurnal_ipa/article/view/2085

Agustini, D., \& Suardana, M. (2013). Pengaruh model pembelajaran Sains Teknologi Masyarakat (STM) terhadap penguasaan materi dan keterampilan pemecahan masalah siswa pada mata pelajaran IPA di MTS Negeri Patas. Jurnal Pendidikan Dan Pembelajaran IPA Indonesia, 3(1). https://doi.org/10.33394/ mpm.v3i2.1833

Amalia, S. (2019). Pengaruh pendekatan SETS (Science, Environment, Technology, Society) terhadap literasi sains dan sikap ilmiah peserta didik kelas VII di SMP Taman Siwa Teluk Betung [UIN Raden Intan Lampung]. http://repository.radenintan.ac.id/6140/

Anugrah, V., Pramana, R., \& Pudji, S. (2021). Learning Bryophyta: Improving students' scientific literacy through problem-based learning. Jurnal Pendidikan Biologi Indonesia, 7(1), 71-82. https://doi.org/10.22219/ jpbi.v7i1.15220

Burden, K., \& Kearney, M. (2016). Future scenarios for mobile science learning. Research in Science Education, 46(2), 287-308. https://doi.org/10.1007/s11165-016-9514-1

Bybee, R., McCrae, B., \& Laurie, R. (2009). PISA 2006: An assessment of scientific literacy. Journal of Research in Science Teaching, 46(8), 865-883. https://doi.org/10.1002/tea.20333

Chebii, R., Wachanga, S., \& Kiboss, J. (2012). Effects of science process skills mastery learning approach on students' acquisition of selected chemistry practical skills in school. Creative Education, 3(08), 1291. https://file.scirp.org/pdf/CE20120800005_15278842.pdf

Dwipayana, M. (2017). Pengaruh model pembelajaran Sains Teknologi Masyarakat (STM) terhadap kemampuan pemecahan masalah dan self-efficacy siswa. Jurnal IImiah PROGRESSIF, 10(30), 29-41. https://web.archive.org/web/20180419010739id_/https://ejournal.undiksha.ac.id/index.php/JIPP/article/vi ewFile/11968/7639

Eliyanti, E., Hasanuddin, H., \& Mudatsir, M. (2019). Penerapan handout berbasis pendekatan SETS (Science, Environment, Technology, And Society) pada materi bioteknologi terhadap hasil belajar siswa MAS Darul Ihsan Aceh Besar. BIOTIK: Jurnal IImiah Biologi Teknologi Dan Kependidikan, 6(2), 105. https://doi.org/ 10.22373/biotik.v6i2.5615

Ghofur, A., \& Raharjo, N. R. B. (2018). Peningkatan kemampuan berfikir kritis mahasiswa melalui pendekatan 5E dan SETS berbantu aplikasi media sosial. JINoP (Jurnal Inovasi Pembelajaran), 4(2), 102. https:// doi.org/10.22219/jinop.v4i2.6678

Gultepe, N. (2016). High school science teachers' views on science process skills. International Journal of Environmental and Science Education, 11(5), 779-800. https://doi.org/10.12973/ijese.2016.348a 
Hadi, W. P., Munawaroh, F., Rosidi, I., \& Wardani, winda kusuma. (2020). Penerapan model pembelajaran discovery learning berpendekatan etnosains untuk mengetahui profil literasi sains siswa SMP. Jurnal IPA \& Pembelajaran IPA, 4(2), 178-192. https://doi.org/10.24815/jipi.v4i2.15771

Handayani, H., \& Widiantie, R. (2020). Pre-services biology teachers: correlation of metacognition awareness with the ability to design experiments through vee diagram. Biosfer, 13(1), 143-154. https://doi.org/ 10.21009/biosferjpb.v13n1.143-154

Harlen, W. (2014). Helping children's development of inquiry skills. Inquiry in Primary Science Education (IPSE), 1, 5-19. https://ipsejournal.files.wordpress.com/2015/03/3-ipse-volume-1-no-1-wynne-harlen-p-5-19.pdf

Hindriana, A. F. (2016). The development of biology practicum learning based on vee diagram for reducing student cognitive load. JETL (Journal Of Education, Teaching and Learning), 1(2), 61. https://doi.org/ 10.26737/jetl.v1i2.39

Holbrook, J., \& Rannikmae, M. (2009). The meaning of scientific literacy. International Journal of Environmental \& Science Education, 4(3), 275-288. https://files.eric.ed.gov/fulltext/EJ884397.pdf

Indriati, D. (2012). Meningkatkan hasil belajar ipa konsep cahaya melalui pembelajaran Science-edutainment berbantuan media animasi. Jurnal Pendidikan IPA Indonesia, 1(2), 192-197. https://doi.org/10.15294/ jpii.v1i2.2138

Khizar, H. M. U., Rasheed, H. M. W., Iqbal, M. J., Akhtar, K., \& Khalid, J. (2020). Student impression management and academic performance : A moderated Student impression management and academic performance: A moderated mediation model. Wiley Academic Paper, 1-13. https://doi.org/10. 1002/pa.2258

Mchaidir, M.D., Redjeki, S., F. Hindriani, A., K. Suprapto, P., \& Badriah, L. (2018). Analisis kecerdasan ekologis mahasiswa calon guru biologi melalui model pembelajaran berbasis masalah dengan bantuan diagram Vee. BIOSFER: Jurnal Biologi Dan Pendidikan Biologi, 3(1), 1-5. https://doi.org/10.23969/biosfer. v3i2.1244

Nofiana, M., \& Julianto, T. (2018). Upaya peningkatan literasi sains siswa melalui pembelajaran berbasis keunggulan lokal. Biosfer : Jurnal Tadris Biologi, 9(1), 24. https://doi.org/10.24042/biosf.v9i1.2876

Novitasari, N. (2018). Profil kemampuan literasi sains mahasiswa calon guru biologi. BIOSFER Jurnal Tadris Pendidikan Biologi, 9(1), 36-44. https://doi.org/https://doi.org/10.24042/biosf.v9i1.2877

Oktavia, L. (2015). Pengaruh disiplin belajar, partisipasi belajar dan tingkat pendidikan orang tua terhadap hasil belajar siswa pada mata pelajaran analisa riset pasar kelas XI pemasaran SMKN 2 Padang. Jurnal IImiah Mahasiswa STKIP PGRI Sumbar, 1-11. http://jim.stkip-pgri-sumbar.ac.id/prodi/dj?page=37

Pratiwi, S. N., Cari, C., \& Aminah, N. S. (2019). Pembelajaran IPA abad 21 dengan literasi sains siswa. Jurnal Materi Dan Pembelajaran Fisika (JMPF), 9(1), 34-42. https://doi.org/10.20961/jmpf.v9i1.31612

Purwani, L. D., Sudargo, F., \& Surakusumah, W. (2018). Analysis of student's scientific literacy skills through socioscientific issue's test on biodiversity topics. Journal of Physics: Conference Series, 1013(1), 12-19. https://doi.org/10.1088/1742-6596/1013/1/012019

Rahayuni, G. (2016). Hubungan keterampilan berpikir kritis dan literasi sains pada pembelajaran IPA terpadu dengan model PBM dan STM. Jurnal Penelitian Dan Pembelajaran IPA, 2(2), 131-140. https:// doi.org/10.30870/jppi.v2i2.926

Ruvalcaba-Romero, N. A., Fernández-Berrocal, P., Salazar-Estrada, J. G., \& Gallegos-Guajardo, J. (2017). Positive emotions, self-esteem, interpersonal relationships and social support as mediators between emotional intelligence and life satisfaction. Journal of Behavior, Health \& Social Issues, 9(1), 1-6. https://doi.org/10.1016/j.jbhsi.2017.08.001

Saptasari, M., Sunarmi, S., Sulasmi, E. S., Wicaksono, R. S., \& Sudrajat, A. K. (2019). Information literacy skill: An alternative to support biology student's learning outcomes. JPBI (Jurnal Pendidikan Biologi Indonesia), 5(3), 451-458. https://doi.org/10.22219/.jpbi.v5i3.8768

Setiawati, H., \& Corebima, A. D. (2018). Improving students' metacognitive skills through science learning by integrating PQ4R and TPS strategies at a senior high school in Parepare, Indonesia. Journal of Turkish Science Education, 15(2), 95-106. https://doi.org/10.12973/tused.10233a

Suprapto, P. K., \& Rahmawati, L. (2017). The influences of Vee diagram on animal ecology lab to learning outcomes and logical thinking. EDUCATIO: Journal Of Education, 2(2). https://doi.org/10.29138/ educatio.v2i2.180

Sofianto, E. W. N., Wartono, W., \& Kusairi, S. (2016). Pengaruh balikan formatif terintergrasi strategi pembelajaran Diagram Vee dan kemampuan awal terhadap penguasaan konsep siswa. Jurnal Pendidikan Fisika Indonesia, 12(2), 183-188. https://doi.org/10.15294/jpfi.v12i2.4269 
Suprapto, P. K. (2017). The influences of Vee Diagram on animal ecology lab to learning outcomes and logical thinking. EDUCATIO : Journal of Education, 2(2). https://doi.org/10.29138/educatio.v2i2.180

Suwono, H., Mahmudah, A., \& Maulidiah, L. (2017). Scientific literacy of a third year biology student teachers: exploration study. KnE Social Sciences, 1(3), 269. https://doi.org/10.18502/kss.v1i3.747

Sya'ban, M. F., \& Wilujeng, I. (2016). Pengembangan SSP zat dan energi berbasis keunggulan lokal untuk meningkatkan literasi sains dan kepedulian lingkungan. Jurnal Inovasi Pendidikan IPA, 2(1), 66. https:// doi.org/10.21831/jipi.v2i1.8369

Trihastuti, Y. (2017). Pengaruh penerapan model SETS (Science, Environment, Technology, And Society) terhadap literasi sains siswa kelas VII SMP pada tema pencemaran air. Jurnal Cakrawala Pendidikan, 53(9), 21-25. http://journal.student.uny.ac.id/ojs/index.php/ipa/article/view/7431

Wicaksono, A. T. (2018). Comparing lab-work learning assisted with Vee diagram and lecturing-demonstration in improving students learning motivation and outcomes on buffer solution topic. 6(1), 6-10. https:// doi.org/10.17977/jps.v6i1.11533

Yolida, B., Marpaung, R. R. T., \& Handini, R. (2021). Problem based learning model using vee diagrams on students' scientific literacy of environmental pollution material. JPBIO (Jurnal Pendidikan Biologi), 6(1), 55-63. https://doi.org/10.31932/jpbio.v6i1.834

Yuliati, Y. (2017). Literasi sains dalam pembelajaran ipa. Jurnal Cakrawala Pendas, 3(2), 21-28. https:// doi.org/10.31949/jcp.v3i2.592 